\title{
Confronting COVID-19 in 'Social Class in America': Research and Reflections by Working-Class Student-Scholars
}

\author{
Edited by Sara Appel ${ }^{1}$, Lewis and Clark College, Oregon
}

\section{Editor's Introduction}

For the second summer in a row, the editors at The Journal of Working-Class Studies were generous enough to provide several freshman students from my 'Social Class in America' course at Lewis and Clark College the opportunity to publish their research papers. Predicting that I'd have many excellent essays to choose from-this publication opportunity is a great incentive for students to do their best work-I decided to structure our essay project around a unifying theme this time: though, as I told my students right before spring break, I'd wait to see how their essay topics and rough drafts were taking shape before choosing a theme and issuing invitations to submit.

Then COVID-19 hit, and the semester became something unprecedented. Plopping a container of wet wipes down on the table at the front of my classroom, I handed out mini-cupcakes during what was to be our final brick-and-mortar class together, as we'd learned just a few days before. To say my students were anxious would be a laughable understatement. Several were lamenting how, though they'd originally planned on sheltering in place on campus, the school was now saying they had to pack up and go home within 48 hours; 'Where am I supposed to put my stuff?', 'How am I supposed to get a flight?', 'Is it even safe to be on a plane right now?', were all questions we tried to address, in addition to another that I knew was on everyone's mind: 'How the hell am I supposed to write an 11-13-page research paper from home, with no library?' I decided to make the theme of this summer's student essay project one that would address a version of that question, then: how my students from working-class and poverty backgrounds, in particular, rose to the challenge of trying to research and write a major college essay in the middle of a global pandemic.

In a questionnaire I asked each author to submit along with their essay, my four contributors shared a number of experiences common to poor and working-class college students that were exacerbated by COVID-19, or revealed as especially significant under the pandemic's glaring light. Several mention food insecurity or inconsistency as an issue that, absent the campus dining hall, they had to contend with while trying to attend Zoom classes and conduct research. Most also mention space and privacy constraints. 'I struggled with finding physical spaces [where] I could have a clear mind and enter my productive 'zone," one student revealed; another recalls trying to 'do online school at the same time' as her 'disabled parttime teacher mother,' in the same small apartment. The guarantee of a secure internet connection, electricity, or other technologies necessary to conduct research remotely was also a major source of stress. 'I lived in fear that our internet or power would get shut off, which of course would affect my research process,' one student said. Moreover, in what appears to have had an across-the-board impact on newly-

\footnotetext{
${ }^{1}$ Sara Appel is an adjunct professor of humanities and an academic developmental editor. She lives in Portland, Oregon.
} 
minted 'online' liberal arts college students from all class backgrounds, each student-essayist noted how difficult it was to be torn away from their community of peers while still being expected to produce quality academic work. 'I lost the ability to bounce ideas back and forth with my classmates, and had to rely on my own motivation to get this project done with the same high expectations that I had before the pandemic,' one contributor aptly admits. 'Without [continuously] seeing my peers, I had no idea how to really gauge where I was supposed to be in my process,' adds another.

But the impact of financial stress on health-where health implies both the looming threat presented by COVID-19's own mysterious, terrifying trajectory and the psychological trauma caused by major upheavals of everyday life - was far and away the most significant issue my student-contributors faced as they returned home. 'I lost all three jobs that I was working [on campus],' one student shared; 'I need to work to afford to keep going to college and it heavily impacts my mental state.' Relatedly, the possible loss of scholarships has been heavy on their minds. One contributor's comments especially capture that sentiment: 'I found myself wondering... if I'd still be able to attend my chosen college next year, would switching to a community college be more cost-effective if classes continued online, would I be able to work this summer as I planned - there were many, many worries of this sort on my mind that caused stress.' Another student misses the 'structure and control that came with being an independent college student.' She elaborates: 'I think that other working-class students would agree that life in college is sort of an escape from the chaos and disorder that is custom at home... Among the clutter of dirty dishes or unfolded laundry, there is always a veil of stress in my house because financial struggle rarely allows people to relax.'

Despite these ongoing struggles, the four students contributing to this essay project nevertheless went on to write some of the finest research papers across two sections of my class, all on topics that felt both personal and deeply political to each of them. Josie Graydon, who's never had the privilege to own her own car ('besides a 1995 Jeep Grand Cherokee... which ran for about two days'), investigates the role class plays in the use and quality of public transportation systems. Geo Langer wowed me with the frankness and intimacy of the interviews she conducted with six young, queer-identified sex workers-all of whom reached out to her after a call for participants that she posted on her Twitter and Instagram accounts. Ashleen Smith's close-analysis of the pretense to 'documentary' realism in Shelby Lee Adams' photographic archive of Appalachian holler-dwellers was prompted, in part, by Smith's own childhood discovery of a book of Adams' photographs in her 'Papa's attic.' Jezza Hutto-who struggled early on to nail down a research topic that she felt both emotionally and intellectually drawn to - shares a thoughtfully researched essay in which she argues that it is poor and working-class folks who tend to live in environmentally sustainable ways, rather than the more privileged consumers claiming sustainability as a 'lifestyle.' Read on, for more of these young scholars' impressive work.

$$
* * *
$$

\section{What Does it Cost to be Green?}

\section{By Jezza Hutto}

In recent years, the environmental movement has made its way to the forefront of American mainstream media and society. While public discourse and consciousness raising is important to foster any type of 
social change, mainstream environmentalism in the United States has been restrained by the 'relentless ability of capitalism to commodify dissent' (Maniates 2001). This can also be referred to as 'retail activism,' when governments and corporations capitalize on social movements for profit. With this commodification comes exclusion, as economic inequality runs deep within our country's foundation. In the contemporary environmental movement, 'Market-oriented Sustainability', 'Green Capitalism' and 'eco-friendly' are strong indicators of commitment, encouraging consumers and companies to literally buy into the cause (Moser 2018). This dominant narrative of environmentalism as a simple change in consumer choice marginalizes those who cannot afford to participate, allowing class status to be a deciding factor in the membership of the fight for our planet.

This essay will provide insight toward a greater consideration of how class affects people's ability to lead a sustainable life and participate in the contemporary environmental movement in the United States. In order to help understand this issue, I will consider four questions in sections titled accordingly: (1) What does the current environmental movement look like? In this section, I will look at how the hegemonic ideologies in the current movement largely reflect 'environmental elitism.' (2) What is the perceived and actual relationship between class and environmentalism? This section will attempt to dispel misinformation about poverty and environmentalism by comparing environmental impacts of different classes. (3) How is the current state of the movement harmful and exclusionary? For this question, I will examine how the commodification of environmental activism negatively affects low-income participants and the movement as a whole. In the last section of the essay, I will attempt to answer the question of (4) what would a more effective and inclusive environmental movement look like?

In the United States, many studies have shown that low-income and minority communities are affected disproportionately by the physical impacts of environmental degradation. A 1992 article published by the Environmental Protection Agency Journal found that three out of four toxic waste sites were located in low-income/ minority communities, two million tons of dangerous radioactive chemicals have been dumped on Native American lands, and three hundred thousand Latino farmers suffer from pesticiderelated health problems (Adams 1992). These findings, among others, sparked the Environmental Justice movement, which criticized mainstream environmentalism for overlooking factors of race and class in its politics (Greenberg 2013). Disproportionate environmental impact is one of, if not the most rampant and thoroughly researched inequalities in environmentalism, but it is not what this essay is about. While it is important to note that there will be intersections with the scholarship of Environmental Justice, this essay aims to analyze how the current ideologies of environmentalism cause the movement to be exclusionary and harmful to low-income people socially and politically rather than physically. Not only do low-income and minority communities physically experience environmental degradation disproportionately, they are also silenced in discourse and immobilized in action because of the focus on consumption.

\section{(1) The Current State of Environmentalism}

A survey by Global Web Index shows that the majority of people believe that 'Individuals/ consumers' are responsible for the future of the environment (Young 2019). As seen in figure 1, 52\% of people believe that 'Manufacturers/ production bodies' are responsible, and 50\% believe that 'National government' is responsible, both falling nearly $20 \%$ short of the belief in individual responsibility. This belief is promoted by governments and corporations via commercialization of the movement, as it relieves them of the responsibility to enact sustainable policies and practices (Maniates 2001). According to environmental sociologist Michael Maniates, '[Mainstream environmentalism] embraces the notion that knotty issues of 
consumption, consumerism, power and responsibility can be resolved neatly and cleanly through enlightened, uncoordinated consumer choice' (Maniates 2001). Environmentalism today is constructed to put responsibility in the hands, and wallets, of consumers.

$\%$ who say the following people/bodies are most responsible

for the future of the environment

Individuals/consumers $\quad 70 \%$

Manufacturers/production bodies $\quad 52 \%$

National government $\quad 50 \%$

National government

$\begin{array}{ll}\text { Local government } & 41 \%\end{array}$

L

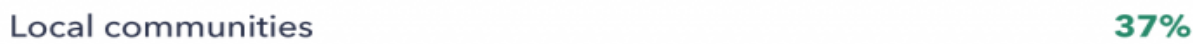

Local communities

International regulatory bodies $\quad 34 \%$

International regulatory bodies

Brands/advertising insititutions $\quad 33 \%$

Brands/advertising insititutions

Influencers/celebrities $\quad 19 \%$

Figure 1: Young, K. From GlobalWebIndex Blog, 27 November 2019. Viewed 23 April 2020.

The popular environmental movement revolves around two things: marketing and consuming. A movement that was originally deployed by countercultural and grassroots groups to challenge the status quo has now gone corporate (Greenberg 2013). We can see 'sustainability' being used as a marketing tool by car companies, clothing brands, real estate firms, entertainment industries, restaurants, colleges, and politicians (Brisman 2009). Plant-based products, hybrid cars, recycled shoes are advertised as the simple way to do our part (Maniates 2001). Take, for example, the introduction of reusable straws in an effort to save sea turtles and help clean the ocean. The widespread plastic straw ban addressed less than one percent of ocean pollution, but because banning straws does not require any major lifestyle change for most people, the anti-straw campaign took off (Ivanova 2019). People find comfort in buying these supposedly sustainable products because they believe that they're helping the cause and making a difference.

\section{(2) Relationships Between Class and Environmentalism}

While there is a substantial amount of scholarship surrounding the relationship between poverty and environmentalism in the Global South, this essay aims to analyze the effects that class difference within 
the United States has on environmental impact and awareness. There is a misconception that the urban poor are less aware of their environmental impact, resulting in them leading less sustainable lifestyles (Moser 2018). One study published in the Journal of Environment \& Behavior found that higher income is associated with a greater environmental self-identity, or a self-proclaimed 'eco-consciousness' (Moser 2018). While this may seem to reinforce the misconception about a lack of environmental consciousness in poor communities, it is very important to make the distinction between intent and impact. The same study that found a positive correlation between income and consciousness found that actual impacts did not follow this pattern. It states, 'people high in environmental self-identity in our sample used slightly more energy and had a slightly bigger carbon footprint than those indicating less environmental awareness' (Moser 2018). This goes to show that while people may readily identify with the environmental movement, their lifestyles do not always reflect this, suggesting that mainstream environmentalism is largely symbolic. This underrepresentation of low-income people who self-identify as environmentally aware can be attributed to the commercialization of the movement.

\section{Grassroots Sustainable Lifestyles}

Statistics continually show that despite having a pro-environmental stance, middle and upper-class households have a greater environmental impact than lower-class households. Larger houses use more energy and water because of average household activities and a higher maintenance demand. More affluent families emit more greenhouse gases via multiple cars and more frequent air travel (Moser 2018). While it may be economically motivated rather than environmentally, poor people engage in sustainability practices such as public transportation, limited travel, second-hand shopping, and less unnecessary consumption (Satterthwaite 2003). Low-income folks may purchase reused products such as cell-phones and cars, and while these consumption behaviors are not explicitly labelled 'eco-conscious,' they are still more sustainable than buying brand new products. If more goods were able to pass through multiple consumers before they are disposed of, there would be less demand for new products, lessening the environmental impact of the manufacturing industry (Zink 2016).

Consumption patterns are a major indicator of differences in environmental impacts between higher or lower income households. 'In urban areas, it is overwhelmingly the consumption patterns of non-poor groups (especially high-income groups) and the production and distribution systems that serve them that are responsible for most environmental degradation' (Satterthwaite 2003). There is a major paradox here: middle and upper-class people feel as though participating in consumption-based environmentalism is making a positive impact, but it is the consumption patterns in general that make the difference. While some eco-friendly products may actually be more sustainable than their counterparts, they encourage consumption nonetheless. Virtually all products have an adverse impact on the environment, requiring natural resource extraction and releasing waste and emissions (Zink 2016). In fact, an article published in the Stanford Social Innovation Review raises an interesting point: 'Maybe the advertised greenness of the energy-efficient gadget even encouraged the consumer to purchase it instead of not buying anything' (Stanford). For those who can afford to change their consumption patterns, it may be more effective to 'foster the capacity for restraint' that lower-income people practice unwillingly (Maniates 2001).

\section{(3) Why Current Mainstream Environmental Thought is Harmful}

There is an abundance of evidence that low-income people tend to have more sustainable lifestyles, yet they are less present in the environmental movement. This is largely due to the fact that membership in 
the movement relies on one's ability to participate in green consumerism. By basing allegiance to a social movement on consumerism, the movement becomes divided by class differences. Products that are advertised as environmentally friendly are usually more expensive than their conventional counterparts, creating an 'environmental elitism' (Ivanova 2019). Environmental elitism is the outcome when lowerincome people are underrepresented in the leadership, participation and politics of the environmental movement, oftentimes because of its consumer-driven nature (Brisman 2009).

The indicators of being environmentally 'woke' are eco-friendly products and technologies such as hybrid cars and organic food. In a journal article published by The North Dakota Law Review, green criminologist Avi Brisman says, 'Goods have symbolic meanings in all societies' (Brisman 2009). Eco-friendly products that appeal to the wealthier consumer are becoming a status symbol, as they reflect not only a person's environmental 'wokeness' but also the numbers in their bank account (Ivanova 2019). One study from The North Dakota Law Review surveyed hybrid car owners and found that $57 \%$ of them said they bought it to make a statement about themselves (Brisman 2009). While wanting to display environmental commitment may send the message of 'I am greener than thou,' it also conveys 'I am richer than thou' because of the current state of mainstream environmentalism (Brisman 2009). Many Americans cannot afford to shop their consciousness, and rather than excluding them from the movement, we must create alternative entryways to mainstream environmental activism.

\section{(4) Looking Forward: An Effective and Inclusive Movement}

Commercialized activism does not account for the substantial amount of people who cannot afford the commodity of being green. The issue is not the green products crowding store shelves, but rather the hegemony of green consumerism in the movement. As long as individual consumer choice is at the crux of environmental activism, the movement will remain exclusionary and largely ineffective. Consumption practices reflect and reinforce class hierarchies and systems of power. If people primarily express environmental concern by partaking in 'ritual displays' and 'feel-good' activities such as investing in sustainable technologies and products, green consumerism will remain synonymous with environmental activism (Brisman 2009). In order to cultivate a more inclusive and effective movement, there must first be a recalibration of the core values.

Greed, materialism and excessive consumption fuel the United States' economy, but for the sake of the planet, we must transition to a 'post-materialistic' society (Fairbrother 2013). Whether eco-friendly or not, Americans spend about \$1.2 trillion a year on non-essential items (Whitehouse 2011). Production and manufacturing require immense amounts of natural resources and energy, often dispelling air and water pollution in pursuit of profit. A study in the Journal of Environment \& Behavior found that 'significant numbers of people exhibit both high environmental concerns and high materialistic values' (Moser 2018). The current state of environmentalism suggests that materialism and environmental consciousness can coexist by introducing eco-friendly consumption. However, these values frequently contradict each other in practice and impact level. It is no coincidence that poor people have a smaller carbon footprint since they often cannot afford to indulge in overconsumption.

It is by focusing on the 'consumption problem' as a whole that the environmental movement can appeal to a wider audience and more effectively mobilize its constituents (Maniates 2001). We are made to believe that materialism and consumption are essential components of American life. Too often, humans become accustomed to their ways, finding consistency in concrete values and routines. Through 
commercializing activism, the capitalist system allows people to feel like pioneers of social change without disrupting American life. When we truly become pioneers of social change, we will welcome disruption and face our fear of change. If the well-being of our planet was a priority, individuals would make the conscious choice to conserve more and consume less. Politicians and activists would push for a revolution of consciousness rather than advertising consumerism as activism.

A critical shift in ideals also calls for the relinquishment of the individualism that currently restrains environmental action. According to Maniates, 'New Age Environmentalism fixes responsibility upon all of us equally and, in the process, cloaks important dimensions of power and culpability' (Manitates 2001). Through an emphasis on individual action, market-oriented environmentalism pacifies people and, in turn, relieves governments and corporations of the responsibility that is rightfully theirs. Environmentalism is a cause that should unite people of all backgrounds to take collective action against the economic and political systems that impact our earth the most. We are better off investing time and resources into helping educate people, engaging in dialogue, taking to the streets, petitioning policy decisions, actively supporting pro-environmental politicians, and above all, holding corporations accountable for their actions.

An important factor in cultivating support for environmental activism is widespread and accessible education on environmental issues. While climate science curriculum is being adopted by more public schools, it is still being filtered through a partisan lens. Information on environmental issues should be presented as objective and science-based, rather than framing human-caused climate change as a leftist theory (Czajka 2019). An education campaign would also require accessible information for marginalized groups that are too often excluded from activism and mainstream society in general. In his article 'It Takes Green to be Green,' Avi Brisman states:

'While core environmentalists are well above average in socioeconomic level, public support for the environmental movement is drawn fairly broadly from the full range of socioeconomic data. Supporters of environmentalism do not constitute a socioeconomic elite, rather, support for environmentalism is diffuse in the population as a whole; it is only moderately related to socioeconomic level, and most to education at that' (Brisman 2009).

While low-income people continue to be underrepresented in activist circles, there is evidence that support is widespread and education may be the gateway to participation in these communities.

Effective environmental activism is not selective, exclusive and elite, but rather bridges the gaps of difference to create a diverse body of participants. It bases allegiance not on consumer choice, but on genuine concern, and willingness to make difficult changes. It does not always turn to future technologies, but learns from grassroots sustainable lifestyles. It does not put responsibility in the hands of individuals, but in the hands of politicians and corporations. It does not comply with capitalism, but rather challenges the institutions that commodify social change. It does not value money and materialism, but rather values education, curiosity and discovery. Effective environmental activism does not continue on its current path, but looks to future generations for creative, inclusive and imaginative solutions.

Jezza Hutto is from a small town in north Idaho called Sandpoint. She is planning on majoring in Sociology/ Anthropology with a minor in Environmental Studies. She hopes to travel after her time at Lewis and Clark and gain first-hand knowledge and experience before going back to school to get her 
master's degree. Jezza wants to use her education to further study and understand social ideas and attitudes surrounding climate change and environmental activism.

\section{Shelby Lee Adams and Poverty in American Documentary Photography}

\section{By Ashleen Smith}

I was about nine years old when I first came across the photographic work of Shelby Lee Adams. I was sitting in my Papa's attic office, browsing his extensive collection of photography books, when I saw her staring back at me-a young woman with freckled skin and luminous eyes, photographed in black and white. She was Rosa Lee (figure 1), the frontispiece of Appalachian Legacy, Adams' second collection of photographs of poor families living in isolated portions of the Appalachian region of the U.S. I was captivated, and went through the entire book, reading every story and studying each photograph. To me, these people were almost realer than real, their lives depicted in shadowy, intense frames.

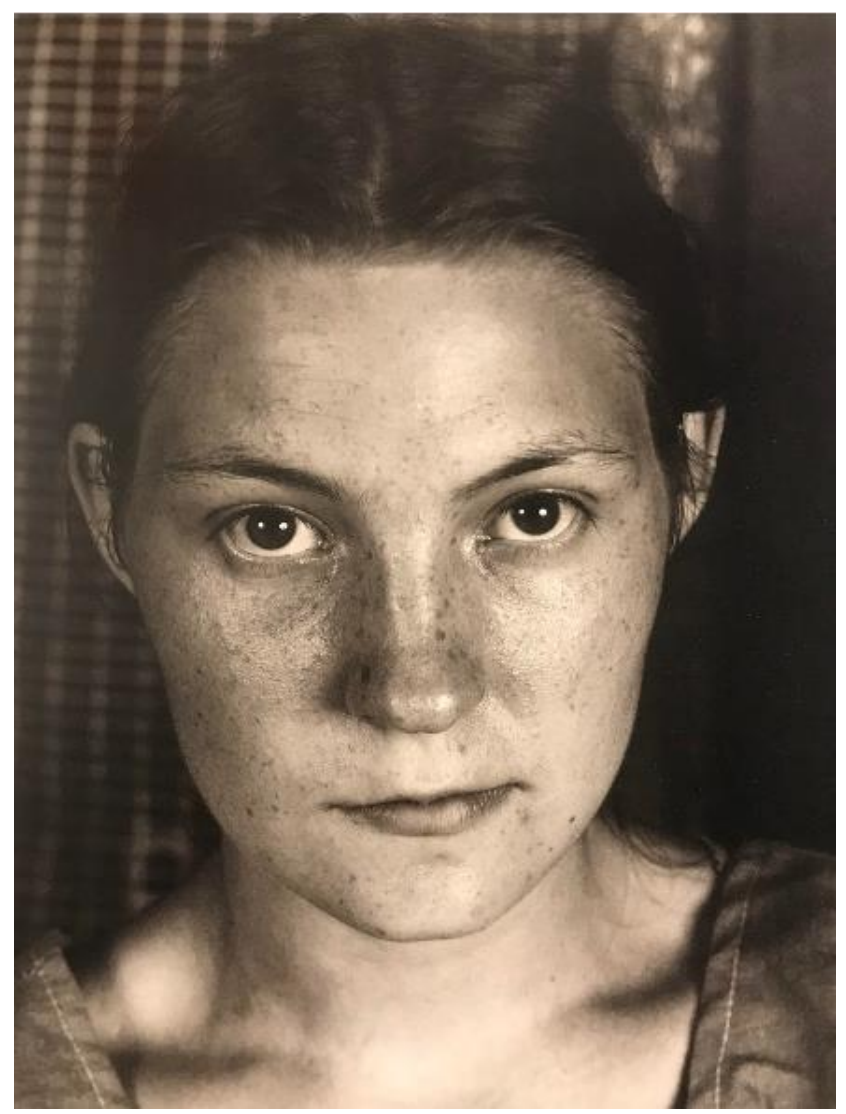

Figure 1: Shelby Lee Adams, Rosa Lee (1986).

Retrieved from Appalachian Legacy, 14 June 2020.

In this essay, I will examine the supposed 'truthful' representation in 'documentary' photographs, when the subject is a community that is heavily stereotyped and faces the added preconceived misconceptions that come with poverty. I will also consider aspects of Shelby Lee Adams' photographic process- how 
he perceives both audience and subjects, his consideration of stereotypes (or lack thereof), his use of aesthetics and framing, and his personally stated intentions - and how they shape the ethics of his work. Through this close analysis, I will attempt to answer the question, is there really such a thing as a true documentary photograph?

Perhaps the most notable large-scale example of documentary photography in the United States is the FSA Photographs. The FSA photographs were part of a public relations project funded by the Farm Security Administration that took place from 1935 to 1944, with the aim of documenting American life as affected by the Great Depression ('About'). It focused on two low-income groups, sharecroppers in the south and migrant agricultural workers in the midwest ('About'). Photographers such as Dorothea Lange and Walker Evans were involved in the project, and from it came some of the most iconic images in American photographic history. These photographs helped establish a sort of visual language, 'an artfully constructed authenticity effect,' that can be seen in documentary photography today, including that of Adams (Fluck 2010, p. 65). The work of Walker Evans, in particular, creates an aesthetic that Adams clearly emulates in his work. Evans' photograph Bud Fields, Cotton Sharecropper, Hale County, Alabama (figure 2,1935), where the subject is posed looking directly at the camera, is a solid example of his use of shadowy portraits. Evans also intentionally posed his subjects, moving items in their homes in an effort to 'achieve a certain balance,' for artistic purposes (Fluck 2010, p. 65).

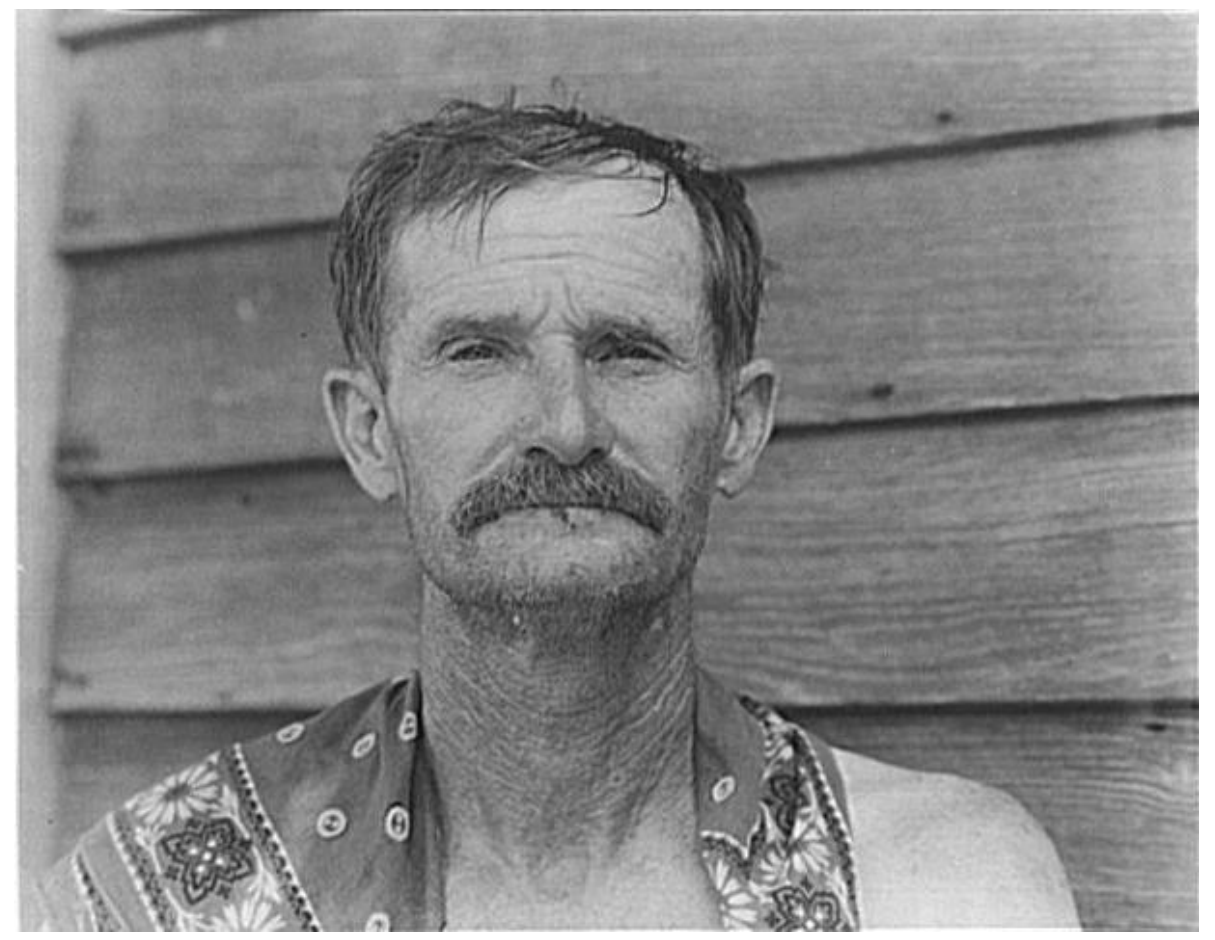

Figure 2: Shelby Lee Adams, Bud Fields, Cotton Sharecropper, Hale County, Alabama (1935). Retrieved from Library of Congress, 13 June 2020.

This specific framing and 'authenticity effect' contradicts my own early idea of Adams' photographs as 'real,' an idea that seems to be shared by many of those who have purchased Adams' books and viewed his art in galleries over the past forty years. The wide appeal of Adams' work is based on the idea that it is documentary, that it 'avoid[s] the pictorial, the sensational, the sentimental, but [speaks] with feeling in the idiom of truth,' as Grace Mayer described the work of the Farm Security Administration photographers 
(Fluck 2010, p. 64). But how documentary is Adams' work, truly? In an attempt to answer this query, filmmaker Jennifer Baichwal directed The True Meaning of Pictures, a 2002 documentary film featuring interviews with Adams' subjects, art critics and sociologists, fellow photographers, and Adams himself.

Early in the documentary, Adams hints at his intentions for his work when he speaks to what he feels is the indignity of early journalist coverage of Appalachia in the 60s, during the 'War on Poverty': 'Maybe I wasn't so pleased with how everything was portrayed either... it wasn't portrayed honestly. The irony is, I'm accused of exploiting my own culture... I'm trying to make right what the media has done wrong' (Baichwal). But are his subjects really 'his culture'? Adams is not a complete outsider to the communities he photographs. He was born and raised in Hazard, Kentucky, near the 'hollers' where many of his subjects reside. But he openly acknowledges that he was never of the same economic status as they were. He 'was - and remains - middle class' (Goddard 2002, p. 26). He became 'like regular kin-people' to some of the families he worked with, in the words of Corinne Zabalda, but Adams does not live in a holler, and he is not subject to negative parts of the Appalachian way of life (Baichwal). He can return to his middle-class home at the end of the day, when his photographs are made.

Adams himself does not consider his photographs to be truly documentary and unbiased: 'I'm photographing from a culture I'm from, I know about... It's not an objective document. It's me, it's life, and it's my subjects' lives, who are my friends, who I love, and care about.' (Baichwal). Multiple conflicts are created by this statement: How is it 'him,' Shelby Lee, but also his 'subjects' lives' when they do not share his social status and living conditions? How do his photographs show 'life' if they are intentionally posed? In further conflict with this sentiment is the title of Adams' most recently published book Salt \& Truth. The use of the word 'truth' produces an idea that any depictions within must be honest, and 'salt' brings to mind phrases such as 'salt of the earth.' This evokes ideas of reliability, and holds up the Appalachian people as a hardworking ideal; appealing to American nostalgia and ideas of a lost past, but also placing the Appalachian people in a bygone time period.

Any discussion of artistic depictions of Appalachians necessitates a look at the stereotypes that have long defined Appalachian people to the larger United States. Dwight Billings, a sociologist at the University of Kentucky, explains some of the common stereotypes surrounding Appalachians, referencing the 1972 film Deliverance: 'The hillbilly is typically male, typically bearded, ignorant, shiftless, drinks moonshine, is involved in petty, violent disputes...' (Baichwal). Deliverance solidified the American perception of the 'hillbilly,' which was further reinforced by the popularity of the 'hillbilly horror' subgenre, as seen in films like The Hills Have Eyes (1977) and The Texas Chainsaw Massacre (1974). 'Laden with vulgar stereotypes, rural-set films often appear to emphasize the depravity, danger, and monstrosity of white rural people and places,' Emily Satterwhite asserts in 'The Politics of Hillbilly Horror' (Satterwhite 2007, p. 227). These films are often the primary form of contact that Americans have, or more accurately, believe they have, with the people of Appalachia, and the stereotypes depicted in them are still accepted commonly.

When using such a heavily stereotyped group as the subject of one's work, especially a group that may not have access to the education and worldview that enables the same levels of artistic understanding enjoyed by those viewing their photographs in a gallery, one must display a level of sensitivity. An examination of Adams' aesthetic choices, in framing, lighting, and other aspects, shows that he may not be as considerate of this ethical conflict as is needed to accurately portray a group surrounded by such misconceptions. 
In an essay for German academic journal Amerikastudien, Professor Winfried Fluck discusses the widely held opinion that 'aesthetic disorientations' are largely not present in the FSA photographs. He argues that those distortions are not only very much present, but also that 'an 'objective' documentary mode possesses an aesthetics of its own which presents merely another way of transforming the poor into aesthetic objects' (Fluck 2010, p. 63). Beyond simply lacking objectivity, documentary photographs, particularly those of the poor, have their own unique set of aesthetics that serve to objectify the subjects, while also making the photographs appear more 'gritty' and therefore be perceived as more realistic. The work of Adams can be analyzed according to this same conclusion. As previously mentioned, many of the aesthetic choices Adams' makes in his photography of the poor, including his choice to photograph exclusively in monochrome, are similar to those used in the FSA photographs, and have the same objectifying effect. They also contribute to the 'authenticity effect' that causes the photographs to be perceived as more true to everyday life and less staged than they are in fact.

Returning to Baichwal's documentary, photography critic A.D Coleman comments critically on the staging of Adams' photographs: 'We can look at some of [Adams'] pictures and see a certain theatrical quality, a sense of the image as a kind of narrative, with events that have been in some ways set up... ' (Baichwal). When it comes to the choices of subjects and framing in his work, Adams seems to focus on somewhat macabre themes as part of this 'theatrical quality', photographing broken toys (The Doll Bed, 1995) and a smiling man holding the severed head of a pig (Sherman with Hog's Head, 1992) (Adams). Photographs such as Appalachian Dracula with Granny (figure 3, 1993), and Jimmy Layne, Halloween Day (1993), make use of the wide-angle lens, which creates a distorted effect that serves to convey discomfort, and lends the subject a menacing aura (Adams). These subjects, combined with shadowy lighting and looming, ominous poses, could highlight the stereotype of the 'violent streak,' or what Coleman refers to as the 'spooky' aspect of Adams' photos (Baichwal). As to why Adams chooses to portray his subjects in a menacing light, one answer comes in looking back to 'hillbilly horror'- the stereotype of the violent Appalachian seems to have a lasting appeal to morbid curiosity.

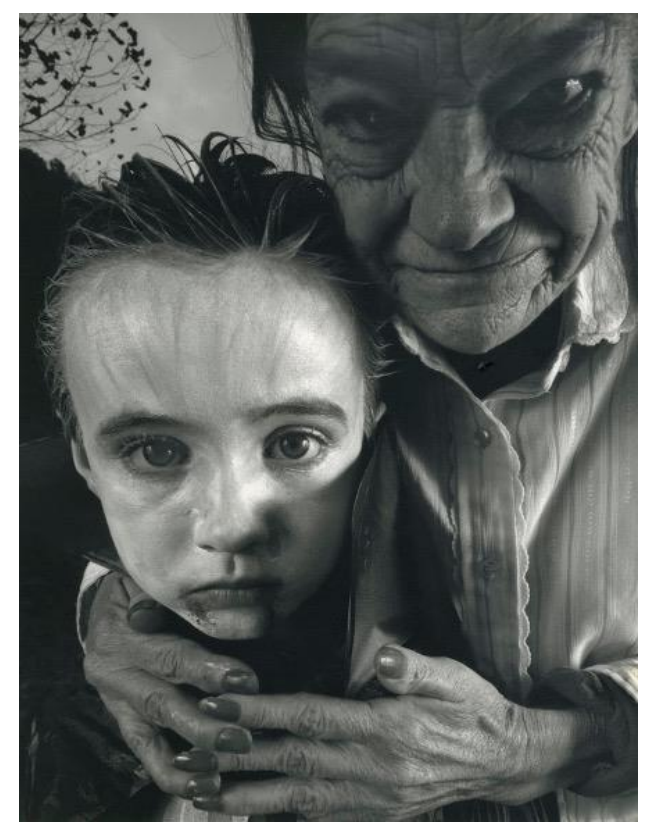

Figure 3: Appalachian Dracula with Granny (1993).

Retrieved from Shelby Lee Adams Blogspot, 13 June 2020. 
Another example of Adams' use of framing can be found in one of his most controversial photographs, The Childers' Kitchen, Neeley Branch (figure 4, 1986). In The True Meaning of Pictures, Adams tells us that he arranged the photograph as a religious tableau. The diaper worn by Homer, Burley Childers' developmentally disabled son, is envisioned as a kind of drapery, similar to the garment that Christ often wears in artistic renderings of the passion and crucifixion. Burley, holding his new knife in his hand, is seen as one of the Roman soldiers involved in Christ's death (Baichwal). Adams was not looking to capture the preparation of a meal in an Appalachian home; he was looking to express a more artistically complex agenda. Author Larry Vonalt, in a journal article that defends Adams, calls The Childers Kitchen 'a collaborative effort,' as 'those photographed are aware of their involvement in making the photograph,' because the photograph is not taken candidly (Vonalt 2006, p. 119).

But how much of a collaborative effort can it really be if the subjects are not aware of the end artistic aim? Adams' 1990 photograph The Hog Killing (figure 5) is another oft-referenced example. This photograph shows the Napier family, frequent subjects of Adams' photographs, smilingly posed around the strung-up body of a dead hog. The body is hung on an archaic-looking wood frame, and the hog's decapitated head is placed in a pan. The Napier family patriarch is holding a shotgun. At first glance, The Hog Killing appears to be a document of everyday holler life. But the photo is completely staged. The method of 'traditional' butchery depicted in the image had not been commonly practiced for a century. Adams gave a friend the money to purchase the pig, and then the Napiers butchered it. Adams says, 'It was like a picture in my mind that we just put together, and everyone had a good time doing it' (Baichwal). Adam's 'picture' was a preconceived notion of a fictional narrative that he desired to communicate to an audience.

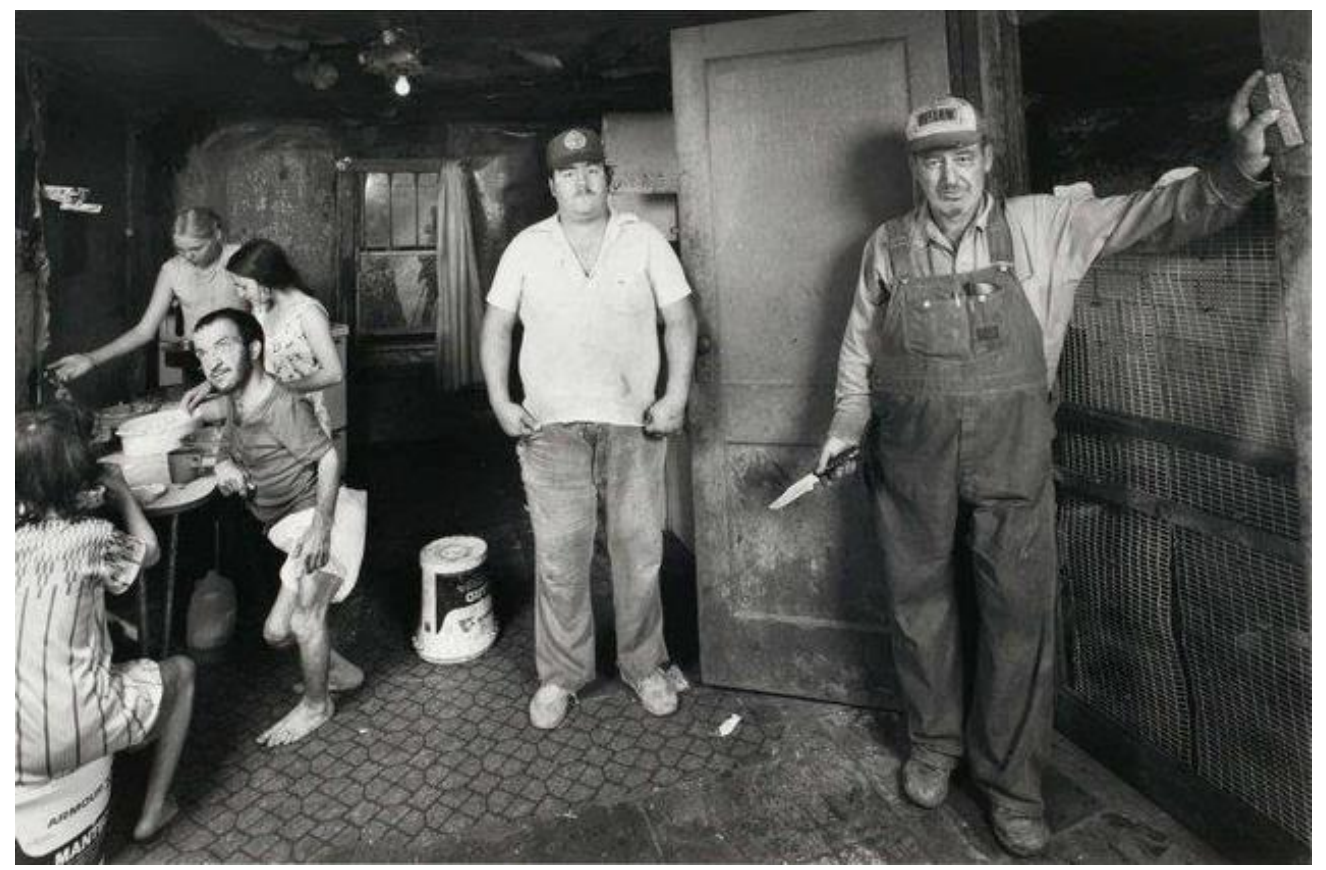

Figure 4: The Childers' Kitchen, Neeley Branch (1986).

Retrieved from International Center of Photography Archive, 14 June 2020. 


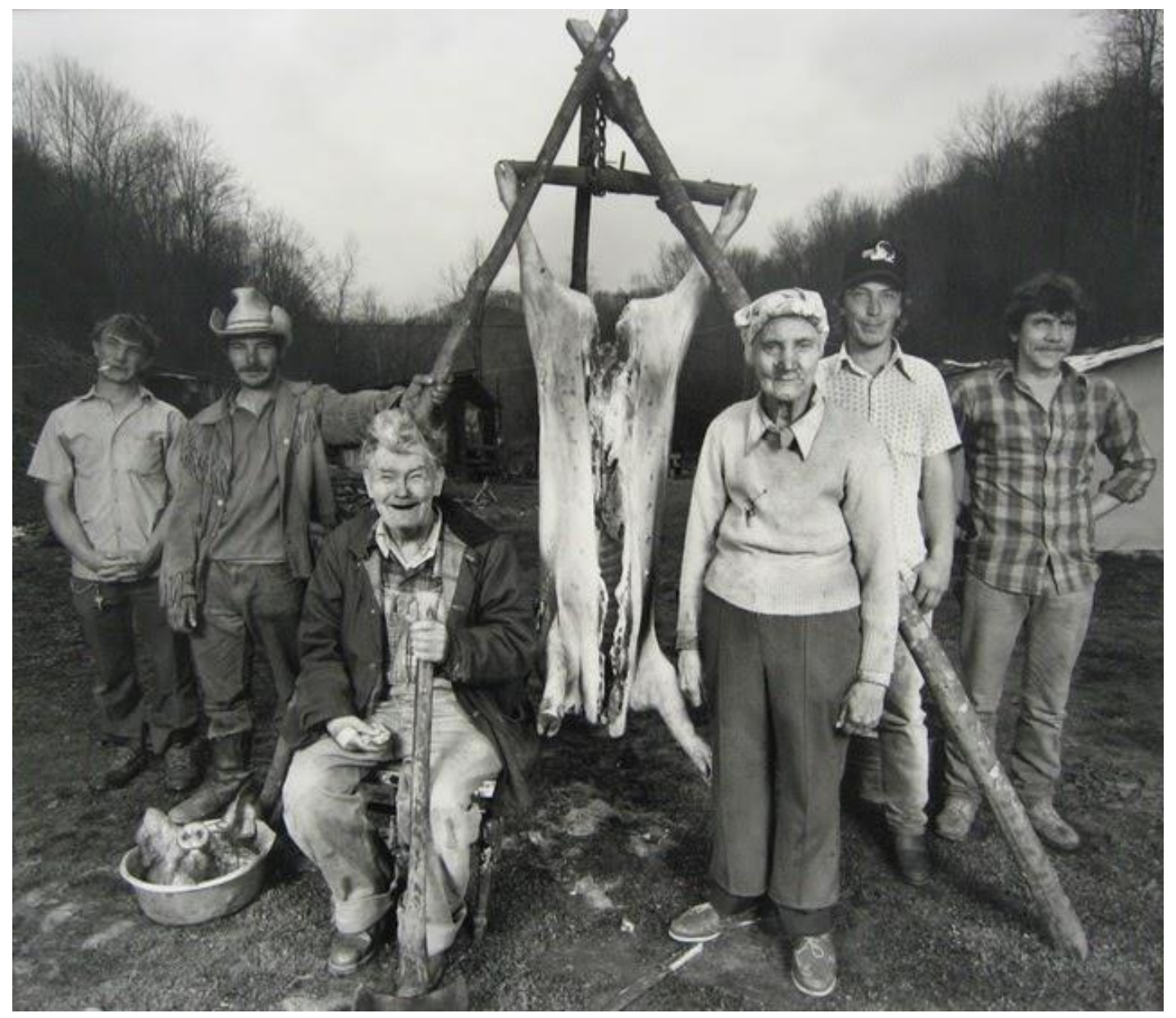

Figure 5: The Hog Killing (1990). Retrieved from PNDB Gallery, 14 June 2020.

Although it does seem, from the footage shown in the documentary, that it was a 'good time,' the photograph is troubling for multiple reasons. With its graphicly slaughtered animal and Mr. Napier holding the shotgun, the photo has an element of violence and the grotesque that is both shocking and promotes stereotypes. The reproduction of an antiquated practice places the Appalachian subjects in the past, and exaggerates the perceived primitiveness of their way of life. The photo also recalls the aforementioned way of posing that was utilized by Walker Evans. Of the photo, historian and photography critic Vicki Goldberg says that 'it is presented as an occasion that happened, and not a representation of something that used to happen' (Baichwal). Author Peter Goddard says that the Napiers 'became actors in the rural drama Adams staged of what he remembered of a ritual hog slaughtering' (Goddard 2002, $p$. 27). The 'authenticity effect' is clearly displayed in this instance. In sociologist Dwight Billings' opinion, the photos 'certainly are telling stories, but the stories are ... left to the viewer to imagine. And we know what the reader is imbued with to imagine: a hundred years of stereotypes.' (Baichwal)

A.D Coleman puts it well when he says Adams' photographs are his 'southern gothic poetry' (Baichwal). The harm may not be so much in Adams' intentions, but in how he uses his subjects to express something within himself. When he speaks of the Childers family, with whom he has an especially close relationship, he says that 'they're the most self-expressive way I can communicate my own feelings and intuition and 
vision as a photographer. It's far beyond documenting a family in Appalachia' (Baichwal). This use is troubling.

In a journal article written on the likely staging of historical photographs taken in the aftermath of the Triangle Shirtwaist Factory Fires of 1911, Tina Margolis describes how tragic events are 'processed through mythmaking- therefore becoming constructed realities to satisfy the human need to distill and encompass experience' (Margolis 2011). Appalachian life is not inherently 'tragic,' but the points that Margolis makes in regard to documentary photography are applicable. Through his artistic choices, Adams is perpetuating an inaccurate myth of Appalachia, forming a 'constructed reality.' This construction fits with the narrative and perception of Appalachia that is personally valuable to Adams - for reasons of nostalgia, storytelling or otherwise - and that 'distills and encompasses' his own experiences, to use Margolis' wording.

Returning to the question of the subjects' understanding is another essential part of examining the authenticity and purpose of Adams' work. Coleman expresses his feelings, saying 'These are photographs... with a great deal of visual sophistication to them, and I think they call for a very sophisticated kind of reading... I'm not sure that the people he's photographing have... the visual educational background to understand how these pictures read' (Baichwal). In The True Meaning of Pictures, Appalachian Louise Hall tells the interviewer that she's 'worked her way up,' continuing, 'I'm so glad that no one came along and took pictures of me and showed them all over the United States, I'm so glad they didn't.' Ms. Hall's reaction contrasts with that of two other women in the documentary, Rachel Riddle, the wife of a serpent-handling preacher, and Corinne Zabalda (nee Napier). Riddle says, 'I don't think that Shelby would take a picture of nobody to make fun of them or to do anything like that.' And in Zabalda's opinion, Adams' work is 'just showing how people in Kentucky really live' (Baichwal). There's a dramatic difference between the feelings of Hall and those of Riddle and Zabalda, and it raises the question: does gaining exposure to the outside world affect the way an Appalachian views how their community is depicted in photography? It appears that most of the people Adams photographs, especially those who remain in Appalachia for most of their lives, are under the impression that the purpose of his work is to show them how they are. Importantly, Adams' work is not meant for his subjects - he shares prints and polaroids and copies of his books with them, but his photographs are clearly aimed towards publication outside of the world of Appalachia.

Out of fairness to Adams, it is notable that in his books his photos are usually accompanied by a written passage that provides some biographical information on the subjects. However, the photograph, with all the biases of its arrangement, is the main focus of each page, and the written accounts are told from Adams' point of view, although they do sometimes contain quotes from the subjects they describe. His descriptions often focus less on the biography of the subjects and more on the story of photographing them: 'In 1992 a friend told me about an old woman who lived in the head of a holler,' he begins one descriptive passage, and many of the other descriptions follow suit in explaining Adams' connection with families and how he began his relationships with them ('Adams'). Once again, these stories seem to be less those of the subjects, and more of Adams' own experiences with them.

In the words of Walker Evans, 'Art is never a document, but it can adopt that documentary style' (Goddard 2002, p. 27). There is no such thing as a truly documentary photograph, as insertion of the artist's intent is unavoidable in any kind of art. True objectivity involves an absence of emotion and motive, and what makes something worth documenting in photographic form usually arises from a motive or emotion. 
However, the artist does have control over how open they are about the extent to which their work values the artistic over the objective. In the case of Adams, his work exists on ground between the documentary and fine art, encompassing and moving beyond documentary photography's uniquely formed aesthetic, but continuing to make objects of the poor.

Objectifying a heavily stereotyped and impoverished group of people and using them to express one's own artistic vision, especially when one is not a member of that group, is inherently unethical, and this is exactly what Adams does. His works may appear to tell the story of the Appalachian people, but in reality, it is Adams' own story being told. But a photograph can still be ethical, even if it is not purely objective. The most ethical way to produce documentary photographs is to put the camera in the hands of the subject being documented. Any insertion of artistic intent will become part of their story, and part of the document being produced, allowing them to share their own truth, and tell the stories that belong to them.

Ashleen Smith is an English major from Madras, Oregon. Her plans include studying abroad and obtaining her MFA in English. In the future, she would like to travel the world, teach high school, and read as many books as possible.

$* * *$

\section{The Nuances of Sex Work}

\section{By Georgia Langer}

A poem by Carol Leigh, from Sex Work: Writings by Women in the Sex Industry (1987)

'Telling a Woman/Driving at Night'

I tell a woman

What work I do for money

Don't you ever feel afraid?

She asks, staring into the headlights

Through a curtain of long, brown hair

Which obscures half her face

Like Veronica Lake

Yes, I'm afraid

Sometimes I try not to feel afraid

Four months ago I was raped

I was afraid of being tortured or killed

I answer, driving my dark green Vega

Wearing a turquoise angora sweater

Dark, red lipstick, new hairdo, good pants

I'm stronger, won't quit

And they're not going to stop me

She laughs and pushes the hair behind her ear

Bars of light drift upward, over our eyes 
If you made jewelry, how much would you sell a set of earrings for? To determine the price, you would likely add the money spent on the materials and combine it with the labor and time spent on crafting it. If you still feel stuck, you could compare it to similar products and price your set of earrings in the same range as others. However, how much would you charge for your body? How do you decide how much your legs are worth? What about your shoulders? Your chest? Your pussy? In the 1960s, rising feminist movements saw sex work as contributing to the patriarchy, excluding these workers from feminist circles. In the book Sex Workers Unite, Melinda Chateauvert addressed this, questioning how 'women of all classes were expected to attract men. So why were women who traded sex for marriage respected, but women who traded sex for money shunned? (Chateauvert 2014, p. 22). Sex work is a form of exchange. In this essay, I analyze the experiences of sex workers to help explain the nuances of the sex industry. The struggles of sex workers give a voice to their stories of gender identity, sexual orientation, and sexual assault in and out of the workplace. I will be addressing the following questions: What makes the job rewarding, and what makes it tough? How do gender identity and sexuality affect someone's role in sex work? What strategies are used to assert boundaries for clients? Does sex work connect or disconnect workers from their sexuality and bodies? Do sex workers find dignity in their work?

I will focus on the stories of six sex workers. To acquire participants for my research, I put out a call on my social media accounts_-primarily Twitter and Instagram — asking to set up an interview with anyone who has experience in the sex industry. In the article 'Sexual Assault Survivors Who Exchange Sex,' sex work is defined as, but not limited to, 'street-based sex work, escort services, call-in/call-out work, brothel work, stripping or exotic dancing, sex trades (for food, money, drugs, housing, etc.), bondage, discipline, sadomasochism, webcam, Internet/phone sex, and pornography' (Shepp, O'callaghan, Kirkner, Lorenz, \& Ullman 2020). The six workers I interviewed do not know each other, and I did not know most of them were sex workers until they replied to my request. If the reader takes away anything from this project, I hope it is the fact that, without a doubt, someone you know and love is a sex worker. Someone you care about and see on a regular basis is in this industry, and for the safety of sex workers, it is our responsibility to respect and protect them.

In late August 2019, a crowd leaked into a busy city council room in Minneapolis, Minnesota to deliberate details of a new bill proposal that sought to enforce safer working conditions in area clubs. When the available seats were filled, many sat on the floor, filed in like sardines in the back, or sat and listened in the hallway outside. This was a typical city hall meeting, except one of the women in the audience was wearing stilettos paired with a red faux leather bodysuit, while other women were wearing wigs, long sleeves, and huge sunglasses. Who were the audience members? Sex workers of different genders, sexual orientations, and ethnicities, who all carried fierce opinions about their work.

The council meeting lasted two hours. Sex workers came up to the podium one by one, sharing their needs as participants in the legal sex industry. Some mentioned loose and/or raised nails on the dance stages. Some wanted VIP areas to install video cameras, and some were extremely opposed to this. Others wanted full control over their money, asking for an end to mandatory tipping of the managers in order to keep their names on the schedule. Some addressed the racist rules that dictated only one Black dancer was allowed to be on stage at a time. Some introduced themselves with their full names, looked directly into the camera and said they felt empowered and safe when they go to work; others hid behind their costumes and spoke in timid voices about the countless sexual assaults and violent encounters they had faced in the industry, and how scary it was to come to the city council meeting. 
I went to this meeting with Luna, a sex worker interviewed in this project. It was difficult for us to tell if the women in support of their clubs were covering up their bad experiences due to intimidation from their boss, or if they genuinely felt like they were being treated well. Of course, we were hopeful that they truly felt supported at work, but because the legal sex industry is filled with independent contracts that excludes many from taking sick days and having job security, we remained hesitant. However, everyone's experiences in sex work are different, and like any other job, different workers have varying desires and expectations in the workplace.

In her book Toward A Feminist Theory of the State, Catharine MacKinnon, a feminist scholar and activist, infamously argued that pornography 'turns a woman into a thing to be acquired and used,' insinuating that sex work is not an empowering job (Mackinnon 1989, p. 199). When I read this quote to one of the interviewed sex workers named Jane, she laughed and declared, 'The society already turned me into a thing to be acquired and used. They have done that since the day I was born with a vagina ('Jane,' telephone communication, 2 April 2020). According to Jane, her experience with sex work has given her power within the patriarchy. Nina Hartley, a porn star, activist and feminist feels similarly, saying, 'A woman can choose a job in the sex industry and not be a victim. She may become stronger, more selfactualized' (Query \& Montoya 2001, 44:00). These mixed perspectives are brought forth, agreed with and refuted during my interviews with these six sex workers. Several interviewees highlight the intersection of patriarchal oppression with the reclamation of self, to find empowerment or simply cope with trauma. Additionally, all of the interviewed sex workers discuss the incentive of money that enticed them to do sex work in the first place.

Although their sex work experiences are very different, every person I interviewed also identified as a member of the LGBTQ+ community. Furthermore, every person had experienced sexual assault at some point in their lives, and most talk about how these factors have played a significant role in their sex work. Janice Ristock's 2011 book Intimate Partner Violence in LGBTQ+ Lives suggests that LGBTQ+ folks experience partner violence, including sexual violence, at strikingly high rates. Ristock notes that after experiencing partner violence, LGBTQ+ folks have increased rates of being in high risk situations, which include 'trading sex, depressive symptoms, and lifetime alcohol abuse' (Ristock 2011, p. 184). The sex workers interviewed in this project range from ages 18-23, and most come from lower and middle-class backgrounds. However, the demographics of the people I interviewed represent just a sliver of an entire industry. Particularly, five out of the six people interviewed are white, and the other is Latinx. Sex work comes in many forms, and these are the stories of a few, not all. Please know that these interviews will contain explicit language and detailed descriptions of sexual violence.

My first interviewer goes by the name Jane. She is a white pansexual woman who found sex work as a way to use the patriarchy to her advantage. When I asked her to explain how she found herself in the sex industry, she shared:

I was thirteen years old and I had just developed breasts. The neighbor boy down the street was about sixteen or seventeen. My hormones were crazy with my newly pubescent body and it was weird, and scary, and all I wanted to do was try it out. I was molested as a young girl, and when the older neighbor boy eventually touched me, as most men like to do, I understood that men viewed my body as a toy. 
When I was five years old, my uncle did not ever pay me after grabbing my pussy and masturbating to it. The neighborhood boy didn't pay me when he decided to fuck me before I knew how sex worked. He didn't pay after he literally tore apart my vagina; he didn't even pay for the pictures he took of the bloody aftermath.

As a sex worker, I have the control. I get the money, and I get to present a persona of a strong woman who has never, ever in her life let a man touch her without consent. I almost believe the persona myself! I dress up, and my body becomes the safety I never had. I am giving myself power by monetizing the patriarchy (Jane).

The persona that Jane uses to alter her internal mindset is one used by many sex workers. In the documentary Live Nude Girls Unite!, two dancers who worked at a peep-show club called the Lusty Lady shared that putting on makeup 'is like a mask' for them (Query et. al. 2001, 2:48). One commented that 'it's kind of a disguise' to separate their personal lives from their performances (Query et. al. 2001, 3:00). Jane describes putting on her makeup as 'war paint,' and paints her face in dark shades with rosy cheeks. Some sex workers feel empowered when using their sexuality and bodies as a way to profit, and some feel empowered using their identity in a way in which they do not typically present themselves.

Luna is a sex worker who uses his knowledge of the patriarchy to both profit and empower himself, capitalizing on the 'deep' parts of social media. He is a Latinx cis queer man and works with a cis queer female partner in their online sex work platforms. His partner is the face of their business, but Luna does nearly all of the communication with clients. Luna's partner does not enjoy the job because their clients often say disgusting things, and Luna mostly likes the job because of the money. However, both have felt empowered by sex work, from the support of their other sex worker friends and from the swarm of compliments they receive from customers. Luna explains how he eats, sleeps, and dreams sex work:

On our account, we have over 2,000 followers. To put it in perspective, we are on pace to make $\$ 75,000$ this year... I am awake until 3am every night because I am making hundreds of dollars. Sex work was definitely a choice for me. Now, part of me is stuck in it, especially because nothing is guaranteed for us with this generation. Even if I go to college it doesn't mean I will get a career, or money. It is something I am stuck in for sure ('Luna,' telephone communication, 3 April 2020).

Luna enjoys his job enough to continue, and like others, does it primarily for the monetary gain. He says it can be fun, but it is also very exhausting. Luna's college switched to online school due to the COVID19 pandemic, which allowed his online sex work to be more of a full-time job.

Riley, a trans and asexual sex worker, says he has also found more opportunities to do online sex work since COVID-19. He finds empowerment through sex work, but also genuinely enjoys the job. Riley uses his preferred pronouns (he/they) when doing sex work, but doesn't always correct cisgendered/hetrosexual male clients when they use the wrong ones. When I asked why, he responded, 'because they pay. That is my only slight issue with it [sex work]. It makes me feel a little disassociated ('Riley,' telephone communication, 5 April 2020). However, Riley says he typically feels more connected to his body while doing sex work: 
I have already disassociated myself from a large amount of my body, so this way I can have a connection to it that isn't personal. I am asexual, so it means I am much more tuned to whatever the other person is into hearing or saying because it is much less about me (Riley).

Although he knows that sex work is potentially dangerous, Riley says protecting himself is not high on his priority list. This, he suggests, is due to his marginalized gender identity as a trans person and his multiple experiences with sexual assault. Riley's experiences with sexual assault were statistically more likely to happen to him than to a cisgendered counterpart.

According to data collected by the Human Rights Campaign (HRC), 26 percent of gay men and 37 percent of bisexual men report having experienced 'rape, physical violence, or stalking by an intimate partner,' compared to 29 percent of straight men. More drastic differences are seen with women-identifying individuals, where 44 percent of lesbian women and 61 percent of bisexual women report having experienced 'rape, physical violence, or stalking by an intimate partner,' compared to 35 percent of straight women. Additionally, 47\% of trans people will be sexually assaulted in their lifetime (HRC 2020). Although trans sexual assault statistics have been recorded, there is a history of trans identity erasure in sex work. Because of this, limited research has been done about trans individuals and the role they play in sex work.

Claudia, an online sex worker, says her clientele 'unfortunately does not match' her sexuality ('Claudia,' personal communication, 3 April 2020). She works alone at home selling videos, pictures, objects, and chatting with clients. She makes about $\$ 100$ a week when she is regularly active online. She has found her experience to be validating and very rewarding:

I decided to do sex work because I needed money and I knew people would pay. It makes me feel good, and so I thought, why not do it for money? I am in a relationship and my partner is not the most sexual person, so we do not have sex all the time. For me, because I am more sexual, this is a way for me to do things that maybe my partner doesn't want to do in a way that is fair for our relationship. I feel more connected to my body when doing sex work (Claudia).

Claudia has never met a client in person, and says she cannot see herself engaging in penetrative sex with a client in the future. She feels very safe doing sex work, and also has the privilege of doing it online.

As stated earlier, there is a lot of controversy around sex work, especially among the smaller circles of activists. Monica O'Connor wrote a book entitled The Sex Economy, which highlights the negative aspects of sex work, including 'pimping, coercion, violence, sexual child exploitation and trafficking' as significant issues. She did write that there could be potential social benefits to legalizing sex work, but 'that in no other occupation is the body of the person the commodity itself,' which ultimately hinders the claim that sex work is good (O'Connor 2019, p. 2). Here, O'Connor makes a valuable point. When people are selling things like earrings they have crafted, it is an extension of what their body can make, not selling the body itself. However, it is totally possible, but not always the case, for people feel that their body is still theirs after performing sex work. In the article Sexual Assault Survivors Who Exchange Sex, the authors found that ' $23.5 \%$ of sexual assault survivors engaged in sex work following their assault' (Shepp et al. 2020). Additionally, they pointed out how, for sex workers, 'engaging in sex work was related to regaining control over both their lives and bodies post-assault,' and that 'child sexual abuse and sexual assault in adolescence or adulthood may also serve as a pathway to engaging in sex work, through running 
away from abuse at home... and/or making it difficult to set boundaries and develop healthy sexuality later in life (Shepp et al. 2020).

Andy had her first experience doing sex work at age 14 when she needed money to run away from home to escape her abusive parents. Andy is a trans woman, but she grew up most of her life identifying as a gay man, and still identifies as a gay man during sex work. Growing up in the rural south, the first gay man she met was older and online. She describes how older men were 'grooming' her, and other gay boys, into sex work:

For me, and for a lot of young gay men, the way they get into sex work is by not being exposed to other gay people. Being very isolated, we turn to questions online, go on places such as Grinder or Craigslist, and then are preyed upon by older men. It's not like you go on there searching for money. You go on there searching for other young gay kids and then some old man offers you money, and you're fourteen and poor. I don't think anyone really wants to be in sex work, it's more of a grooming process (Andy).

The act of grooming is defined as 'a process by which an individual prepares the child and their environment for abuse to take place, including gaining access to the child, creating compliance and trust, and ensuring secrecy to avoid disclosure' (Williams, Elliott, \& Beech 2013). Andy talks about how grooming tactics are extremely common for gay boys, and this harmful narrative is continued with the normalization of this in the media.

Jane has faced similar issues and talks about the 'foot-in-the-door' psychology approach that a male client uses to guilt her into doing things she feels uncomfortable with. Psychologist Saul McLeod defines this as when 'initially you make a small request and once the person agrees to this they find it more difficult to refuse a bigger one' (McLeod). This tactic can be seen during the grooming process as well, as Jane shares:

My sugar daddy first said that all he wanted to do is chat with me and take some pictures of me, primarily my face. But before I knew it, I took off my clothes and he took pictures of me in lingerie, having me turning around and lifting up my top and panties for him. He also promised that he wouldn't touch me, but after I let him take pictures of me he gave me a big hug. Now, he is asking me if he can take pictures of me masturbating in his home. He thinks that because I complied with one of his requests, he now has wiggle room to ask for things I specifically told him I wouldn't do (Jane).

Jane's experience is not an outlier for the sex industry. Lisa, a cis bisexual woman, shared memories of similar compliance tactics, with heart-wrenching results. Lisa was underage when she did sex work-but her clients, who were all over 30, thought she was 18 . She discusses how difficult it was for her to set boundaries:

I didn't really set boundaries. Looking back, I should have, but I didn't. I wanted it to be more of a relationship, not penetration, but it was more often than not penetration. For a while, I wondered if it was sexual assault. [Long pause.] Currently, I do not have a good relationship with my body, but I don't know if that is a direct relation to sex work. I do not look down upon myself for doing sex work. I do not feel attached to romantic sexual partners either, but I think that has to do with 
my initial experience with sex in my life. I don't think I have the most positive experiences with sex and I think my first time doing anything sexual was... not ideal. I disassociated it from my body. It definitely had an impact (Lisa).

When I asked if she enjoyed performing sex work, Andy confidently said no. She says, 'I do not like my job because I constantly have to be in contact with disgusting, sleazy men.' Luna and his partner have to deal with similar 'disgusting' male clientele. To combat this, Luna uses his past sexual assault experience as a way to 'gain a better understanding of how [his] clients potentially think.' He says his clients have repulsive thoughts, and explains, 'due to my past experience [with sexual assault], I know how to give my clients what they desire. At times my beliefs, morals, and who I am have been put aside to please the client.' Like many others, Luna's main goal in sex work is to gain money. According to him, his sexual assault experience actually aided him in navigating his sex work profession.

When I asked Andy if she thought sex work should be legalized, she paused for a long time before responding: 'I do not want it[sex work] to be legalized, but that is not because I think being a sex worker is undignified. I think it should be decriminalized. But I do not think it should be a market because it opens up for even more avenues for sexual abuse to take place.' By contrast, Riley said, 'I think sex work should definitely be legalized. There should also be extreme repercussions for the abuse of sex workers' (Riley). Most sex work is not legal, and the industry is so stigmatized that most sex workers never report sexual assaults, and the secretive atmosphere takes away support for many workers.

The stigma around sex work, LGBTQ+ identities, and sexual assault makes it difficult for victims to receive aid. One study found that 44 percent of street-based sex workers have been sexually assaulted by the police (Shepp et al. 2020). According to the Washington Post, the statistic for U.S. rapist felony convictions is about $0.7 \%$. In Playing the Whore, Melissa Gira Grant discusses cases where police refused to help rape victims after learning that they were sex workers, adding that 'this isn't about policing sex. It's about profiling and policing people whose sexuality and gender are considered suspect' (Grant 2014, p. 9). These intersecting minority groups are homeless at higher rates, and often report using sex work as a form of survival.

Sex workers have very little systematic power in America. LGBTQ+ people are affected by sexual assault at very high rates. Sex work is a way some people gain power in a society that leaves them powerless. Sex work can be a job of reclamation. When we support sex workers, we are supporting members of the LGBTQ+ community, and victims of sexual assault. At the end of her interview, Jane said, 'If you want to give respect to us [sex workers], the first step is believing all sexual assault claims. Maybe if sex workers actually got help from our communities, we wouldn't have to be working so hard simply to have a voice.' Jane's comment helps explain how sex work discussions often ignore the transparent truth that sex workers are targeted at all facets of their identity. All of these interviews help explain that sex workers are deserving of respect and love.

Sex work brings forth many opposing views, both from outside perspectives and the sex workers themselves. The decision to do sex work, according to these six sex workers, was primarily for money and validation, and subconsciously stemmed from parts of their past sexual trauma, or from their LBGTQ+ identity. Some of these sex workers are very successful at their jobs, and others do it on a less regular basis, only when they need the cash. Overall, these sex workers treat their jobs similar to how other working-class people treat their jobs: like they are jobs. This research has found substantial connections 
between sex work, sexual assault, and LGBTQ+ identity, but this does not undermine the validity of doing sex work for any reason, and the effect it has on the lives of the sex workers. Someone you know is a sex worker, and they should be treated with respect.

Georgia Langer was born in St. Paul, Minnesota, and her family now lives in Minneapolis. She comes from a family of union activists, and is excited about pursuing the activism work that her family has been doing. She is majoring in political science, and is planning to help design and promote comprehensive sexual health curriculum to be taught in schools, and also to distribute menstrual products in countries that lack resources.

$* * *$

\section{Public Transportation: A Vehicle for the Reduction of Social Inequalities}

\section{By Josie Graydon}

Public transportation has the potential to be a great equalizer. Throughout the stages of an individual's life, opportunities to interact with those from a different social class are limited; people grow up going to different schools, playing different sports, shopping at different stores, and working different jobs, all contingent on one's social class. However, transportation is a part of everyone's life, and there are significantly fewer options for transportation compared to schools or stores or jobs. In most major cities, especially within Western society, public transportation systems are a service that is both accessible and extensive (Fleetwood 2004, p. 35). Hypothetically, because it is public and available to anyone who can pay the fare, public transportation 'brings people from different backgrounds together in one place' (Elkin 2015, p. 3). Therefore, because of limited options for transportation, one would think different classes would have the opportunity to interact, or at least coexist with one another within transportation spaces. In reality, this is not the case. Intentional city planning, the idolization of the car, as well as attitudes and stereotypes surrounding public transportation and its users perpetuate and exacerbate class divides.

Although there are not necessarily rules mandating a certain class take a specific mode of transportation, societal norms and expectations act in a way that permits these distinctions to exist. Because of the disparity in mobility between individuals, the upper and middle classes are especially guilty of 'cocooning in homogeneous residential, workplace, and mobility spaces,' with car transport used as a means of middle and upper-class disaffiliation (Boterman and Musterd 2016, pp. 1-4). Ultimately, one must ask, why exactly do such associations with different social classes and specific modes of transportation exist? How does dependency on public transportation for physical mobility affect the lifestyles of those from lower social classes, as opposed to those who do not depend on such systems? How can these systems improve to become more appealing to those from higher social classes, in order to close the mobility gap? There are many ideas to explore when investigating why public transportation is not used as a means to bring those from different social classes together in practice.

When thinking about the role public transportation plays for those living in an urban center, one must consider the structure of the city and its surrounding communities. The level of efficiency and competitiveness within the mobility market in public transportation is dependent upon the structural organization of the city, favoring more central and compact areas (Camagni et al. 2002, p. 214). In Caracas, the capital of Venezuela, those from higher social classes typically live outside of the main city center, in 
areas served poorly by public transportation (Flórez 2000, p. 3). This same can be seen in many Western countries, especially with the construction of suburbs on the outskirts of main urban centers (Flórez 2000, p. 5). Roberto Camagni et al. define urban sprawl as 'low density development, extending to the extreme edge of the metropolitan region and located in a random, 'leapfrog' fashion, segregated in specialised mono-functional land uses, and largely dependent on the car' (2002, p. 201). Typically, newly built, spread-out residential areas outside the city center favor those with increasing incomes, which 'undermine[s] certain traditional features [of the city], such as its compactness and diversity' (Camagni et al. 2002, pp. 200-1). Since only basic facilities are within walking distance, it is assumed each suburbanite owns a car (Wickham and Lohan 1999, p. 4).

With higher-income areas being poorly served by public transportation, the private automobile tends to be the primary mode of transportation (Flórez 2000, p. 3). In a study conducted in four major cities in Europe, inner-city areas always had the lowest rate of car ownership (Wickham and Lohan 1999, p. 10). Due to the possession of a car, individuals from higher social classes can enter and exit city centers whenever they please. However, many lower-class individuals are dependent upon public transportation to enter and exit suburban areas. The extreme car dependency by those from upper classes living within suburban areas outside of the city center affects everyone, even and especially those without cars. Car dependency leads to social exclusion, where members of society are left out of the mainstream due to lack of resources, a private automobile being an especially significant resource (Wickham and Lohan 1999, pp. 2-4).

A phenomenon known as spatial mismatch also impacts the disparity in mobility for those from different social classes. Spatial mismatch acknowledges that wealthier, white populations typically live within peripheral communities in the suburbs, while poorer, minority populations remain in the city center. Then, with the segregation of these distinct populations, the lower-wage jobs created for the lower social classes are also suburbanized (Boterman and Mustard 2016, p.3; Giuliano 2005, p. 64). However, poorer innercity populations are not able to get to the jobs available to them in the suburbs. With this, less job accessibility and fewer opportunities lead to longer commutes and higher unemployment for lower classes within the city, and thus lower net wages (Giuliano 2005, p. 64). It is incredibly clear that the transitdependent are becoming increasingly disadvantaged and isolated as facilities adapt to the contemporary car-dominated world (Steg 2003, p. 27).

Moreover, many upper-class individuals living in the suburbs are quite aware of the limited mobility of the lower class and purposely attempt to bar the transit-dependent from entering the suburbs. In Atlanta, Georgia, the Metropolitan Atlanta Rapid Transit Authority (MARTA) was proposed to combat issues surrounding traffic and pollution within the city, but 'some suburban areas resisted MARTA for fear it would bring Blacks and the poor from the city to outlying suburbs' (Bullard and Johnson 1997, p. 15). The opinions held by the upper-class regarding minorities, individuals of lower-classes, and users of public transportation are strong and rather unfavorable.

For former British prime minister Margaret Thatcher, cars represent individual success and autonomy, and therefore, in regards to public transportation, 'Her model of self-reliance is incompatible with the infrastructure of the city' (Elkin 2015, p. 3). Upon reflection, this seems to be the standard view regarding the private automobile. Originally, the idea of universal car ownership in the Fordist society meant every family had their own car, but now, it is expected that every person has their own car (Wickham and Lohan 1999, p. 4). On the contemporary significance of the car, Wickham and Lohan assert that 'passing a driving 
test is a far more important social ritual today than exercising the vote for the first time!' (1999, p. 2). Many young children dream of the day they get their license and are able to release themselves from the chains of having their parents as chauffeurs. However, this dream is not realistic for everyone. Many adults, including those who possess a valid driver's license, do not have their own personal automobile. In 'Low Income, Public Transit, and Mobility,' Genevieve Giuliano shares statistics on car ownership in the United States: ' $7.7 \%$ of all households have no private vehicle, but $17 \%$ percent of low-income households and $30 \%$ of poor households have no private vehicle. Fully three-fourths of poor households have one or zero vehicles, indicating limited car access' (2005, p. 64). Many individuals of lower socioeconomic status simply cannot afford to purchase and keep a car (Yeganeh et al. 2018, p. 1040). Then, by Margaret Thatcher's standards, are individuals without private transportation considered unsuccessful, inferior members of society?

As the car has evolved to become a status symbol, C. Wright and J. Egan assert that 'anyone who owns a car is perceived as being well-off compared with someone who does not, and can look down on pedestrians as in some sense deprived' (2000, p. 289). Driving allows car users to feel in control, or even more superior to others, specifically to those who do not own cars (Steg 2003, p. 34). Similarly, Wickham and Lohan put it perfectly, arguing that when public transportation is 'abandoned as soon as people have access to the car... public transport users may well be seen as an inferior group' (1999, p. 15). With the increased emphasis placed upon the car in modern society, class divides are reinforced through means of transportation.

Although a person may have a car, they are still able to make use of public transportation if they so desire or require, but they are typically 'assumed to make fewer trips by public transport' (Holmgren 2013, p. 106). In Caracas, Venezuela, it has been shown that members of the higher classes exhibit a willingness to take public transportation; however, as Flórez also concludes, 'higher income users, particularly those owning a car, are very sensitive to quality of service' (p. 1, 13). Along with this sensitivity, regular car users are even less likely to utilize public transportation (and use their cars less) if they view their car as being a significant part of their identity (Steg 2003, p. 34). In other words, members of higher social classes are not completely opposed to using public transportation, but strongly prefer to make use of their private automobiles instead.

Due to the prioritization of funding for building infrastructure that benefits the upper classes, the public transportation systems most commonly used in Los Angeles have increased fares and decreased service (Mann 1997, pp. 70-71). This has decreased the quality of public transportation as well as ridership. This decreased ridership is due to the systems not meeting the standards of individuals that may have the privilege to choose whether or not to use public transportation, as opposed to citizens who depend on it. Therefore, public transportation is seen as an 'avenue of last resort' for many marginalized members of society (Mann 1997, p. 69). Many transit-dependent members of society do not favor their mode of transportation, but have no choice but to use it due to income levels and job accessibility. It has been found that such individuals often find their journeys on public transportation to be depressing, stressful, and boring, the main reasoning being long wait times, unpredictability, delays, and longer travel times compared to those of car users (Gatersleben and Uzzell 2007, p. 427). Because of the predominance of car culture, the transit-dependent exhibit class-based feelings of shame, further perpetuating class divides.

Although public transportation systems more specifically serve those from lower social classes, one could argue the system is actively working against these primary users. For example, residents of Los Angeles 
expressed concerns over the prices of monthly bus passes, as well as infrequent bus schedules (Mann 1997, p. 75). In this case, users within the main demographic of the public transportation systems of Los Angeles provided the city with an opportunity to improve the conditions of the service to make it more user-friendly. However, users were met with the opposite response they were looking for: monthly bus passes were eliminated, making travel even more expensive, and service was reduced on bus lines (Mann 1997, p. 76). With the price of the bus pass already being so high, and the fact that lower-income individuals have to pay a higher fare to use public transportation due to it being a higher proportion of their after-tax income (Giuliano 2005, p. 64), low-income individuals dependent upon public transportation are at a complete disadvantage. Unfortunately, many low-income riders believe that 'public transit is such a poor substitute for the automobile that the poor incur the expense of car ownership to obtain the mobility that a car provides' (Giuliano 2005, p. 64). In Jobstown, Dublin, is has been shown that 'poverty and unemployment are exacerbated by poor public transport' (Wickham and Lohan 1999, p. 8). This statement holds true for most cities that do not commit to improving public transportation systems.

In addition to cities ignoring the requests of transit-dependent users, biases and stereotypes are systematically perpetuated, creating divides amongst communities dependent on public transportation. In San Francisco, 'the fear factor is so strong that most urban centers have special police forces specifically assigned to the transit system,' which target youth of color (Fleetwood 2004, p. 33). Public transportation is a site in which the imagery of youth of color found in media and popular culture is interpreted and carried out in real life. In 'Busing It' in the City: Black Youth, Performance, and Public Transit,' Nicole Fleetwood notes, 'Since its inception, urban public transportation has been a site of racial and class tensions and confrontation in the USA' (2004, p. 36). Because of the extensive history of racism, the media and popular culture pit youth of color against the typically white adults riding public transportation alongside them. Therefore, not only do the perceptions and misconceptions surrounding public transportation and its users create class divides, but they also split the lower class that depends on public transportation systems.

Eric Mann asserts: 'There is a causal relationship between mobility and a potential escape from poverty' (1997, p. 69). Given this information, what can people do to change the narrative and perpetuation of class divisions due to attitudes surrounding public transportation systems? According to Bullard and Johnson, in some counties surrounding Atlanta, taxpayers have subsidized citizens using the park-and-ride system, which increased ridership (1997, p. 15). With increased ridership comes increased capacity, and with increased capacity comes increased quality of service and increased numbers of vehicles in use for bus lines, which in turn decreases wait times (Holmgren 2013, p. 102). If long wait times were originally a concern for those using public transportation, increased ridership will solve that problem. This would decrease the likelihood of the unreliable bus schedules described by transit-dependent users.

There are a variety of solutions that could work to combat the underlying dilemmas and forces surrounding transportation that perpetuate and exacerbate class divides. As put by Boterman and Musterd, it is important to note that exposure to diversity will not immediately bring people of different backgrounds together, but rather provide them with more opportunities to meet $(2016, \mathrm{p}$. 2). At the very least, exposure to diversity through increased ridership by the upper classes will help society stray away from the class associations linked with specific modes of transportation. For example, in Norway, a country that 'has strong socio-democratic political traditions aiming to minimize differences in socio-economic status,' there is less of a correlation between social class and transportation modes (Nordfjærn et al. 2014, p. 97). 
If such trends began to be observed by other countries with large social inequalities, they could mend the modal split.

Further, the modern significance of the private automobile must be diminished. Measures discouraging car usage, such as taxation of fuel, parking controls, and road pricing, can be implemented to encourage using public transportation alternatives (Wright and Egan 2000, p. 288). Structural interventions that 'offer benefits for using alternatives, such as bus or carpool priority lanes or reduced bus fare' are proposed by Heath and Gifford in order to decrease and discourage the use of cars (2002, pp. 2154-5). If measures and interventions are used to promote the use of public transportation as an alternative to the private automobile, the car will be less important to members of society. Once driving becomes more of an inconvenience and public transportation becomes more rewarding, public transportation will be viewed as a more acceptable alternative to cars.

Similarly, as seen in Caracas, Venezuela, 'improved supply and user-oriented policy' makes public transportation services more appealing to those of different classes than the typical transit-dependent users. Thus, if more individuals used public transportation, especially those from the upper classes, more public funding would be devoted to improving public transportation systems. High-quality public transportation makes car ownership less significant, and people are more likely to leave their cars at home, as seen in Helsinki, Finland (Wickham and Lohan 1999, pp. 18-20). With more people willing to ride, this would help make significant strides to improving the attitudes of transit-dependent riders. As far as general welfare, a perpetual cycle of improved public services and decreasing class divisions is much more appealing than a perpetual cycle of low-quality public services and ever-widening class divides. In fact, Linda Steg argues improved public transportation and reduced car use 'will very likely improve their [nondrivers] quality of life, not only because the personal and societal significance of public transport for them, but also because environmental and urban qualities will probably significantly improve in this case' (2003, p. 34). Taking advantage of such benefits could lead to a happier, more balanced society.

Ultimately, many factors contribute to specific class associations with different means of transportation. With intentional city planning, the extreme significance of the car to society, and attitudes and stereotypes surrounding public transportation and its users, class divides will continue to be perpetuated and exacerbated. Public transportation has the potential to bring people of all different backgrounds together into the same space to live amongst and learn from one another. However, many things need to be done to improve the attitudes surrounding public transportation systems, as well as the condition of the travel spaces many low-income people have no choice but to be dependent upon. It is up to us to look past the narrative about public transportation perpetuated by popular culture and the media, for the greater good and the ability to unify as a society against unjust systems that actively work against the marginalized.

Josie Graydon is originally from Bend, Oregon. As a rising sophomore, she is interested in pursuing a degree in Biology, and hopes to work in the field of conservation. She openly shares her class background with others, hoping to empower individuals and bring awareness to the struggles people from lower classes face.

\section{Bibliography}

Jezza Hutto, 'What Does It Cost to Be Green?' 
Adams, J. H. 1992, 'The mainstream environmental movement', EPA Journal, vol. 18, no. 1, p. 25, viewed May 30 2020, <http://search.ebscohost.com.library.lcproxy.org/login.aspx?direct=true\&db=eih\&AN=9609101 $\underline{492 \& \text { site }=\text { ehost-live \& scope }=\text { site }>}$.

Brisman, A. 2009, 'It takes green to be green: environmental elitism, ritual displays, and conspicuous non-consumption,' North Dakota Law Review, vol. 85, no. 2, pp. 329-370.

Czajka, K. 2019, 'States are introducing bills that could prevent teachers from advocating for climate change.' Pacific Standard, 18 February, viewed 5 May 2020, <https://psmag.com/news/state-bills-could-prevent-teachers-from-advocating-for-climatechange>.

Fairbrother, M. 2013, 'Rich people, poor people, and environmental concern: evidence across nations and time', European Sociological Review, vol. 29, no. 5, pp. 910-22.

Greenberg, M. 2013, 'What on earth is sustainable?: Toward critical sustainability studies', Boom: A Journal of California, vol. 3, no. 4, pp. 54-66.

Ivanova, I. 2019, 'Buying 'green' is too pricey for the average consumer', CBS News, CBS Interactive, 12 March, viewed 19 April 2020, <https://www.cbsnews.com/news/buying-green-istoo-pricey-for-the-average-consumer/>.

Maniates, M. F. 2001, 'Individualization: plant a tree, buy a bike, save the world?', Global Environmental Politics, vol. 1, no. 3, pp. 31-52.

Martin, C. 2019, 'Commodifying activism', The Prindle Post, 8 March, viewed 23 April 2020. <https://www.prindlepost.org/2018/10/commodifying-activism/>.

Moser, S. \& Kleinhückelkotten, S. 2018, 'Good intents, but low impacts: diverging importance of motivational and socioeconomic determinants explaining pro-environmental behavior, energy use, and carbon footprint', Environment \& Behavior, vol. 50, no. 6, pp. 626-56.

Satterthwaite, D. 2003, 'The ten and a half myths that may distort the urban policies of governments and international agencies', Institute for Environment and Development.

Whitehouse, M. 2011, 'Number of the week: Americans buy more stuff they don't need', The Wall Street Journal. Dow Jones \& Company, 25 April, viewed 2 May 2020, $<$ https://blogs.wsj.com/economics/2011/04/23/number-of-the-week-americans-buy-more-stuffthey-dont-need/>.

Young, K. 2019, 'Consumers going green: everything you need to know', GlobalWebIndex Blog, 27 November, viewed 23 April 2020, <https://blog.globalwebindex.com/chartoftheweek/green-consumerism/>.

Zink, T. \& Geyer, R. 2016, 'There is no such thing as a green product (SSIR).' Stanford Social Innovation Review: Informing and Inspiring Leaders of Social Change, viewed May 30 2020, <https://ssir.org/articles/entry/there_is_no_such_thing_as_a_green_product>.

Ashleen Smith, 'Shelby Lee Adams and Poverty in American Documentary Photography'

Adams, S.L. 1998, Appalachian legacy, 1st edn, University Press of Mississippi, Jackson.

Adams, S.L. 2003, Appalachian lives, 1st edn, University Press of Mississippi, Jackson.

Adams, S.L. \& Smith L. 1993, Appalachian portraits, 1st edn, University Press of Mississippi, Jackson.

Fluck, W. 2010, 'Poor like us: poverty and recognition in American photography.', 
Amerikastudien / American Studies, vol. 55, no. 1, pp. 63-93.

Goddard, P. 2002, 'Voyeur viewing pleasure (Shelby Lee Adams, from the Toronto-Star).' Appalachian Journal, vol. 30, no. 1, pp. 25-27.

Library of Congress n.d, About this collection: farm security administration/office of war information black-and-white negatives: digital collections: Library of Congress, viewed March 2020, <www.loc.gov/collections/fsa-owi-black-and-white-negatives/ about-this-collection/>.

Margolis, T. 2011, 'Constructed memory and the paradox of empathy: reconsidering an image of the Triangle Fire.' Afterimage, vol. 39, no. 1/2, pp. 25-28.

Satterwhite, E. 2007, 'The politics of hillbilly horror' in M.G Coffey \& J. Skipper (eds), Navigating Souths: Transdisciplinary Explorations of a U.S. Region, 1st edn, University of Georgia Press, Athens, pp. 227-246.

The True Meaning of Pictures 2002, motion picture, Mercury Films, St. Louis.

Vonalt, L. 2006, 'The dignity of Shelby Lee Adams's 'disturbing' family photograph', Studies in Popular Culture, vol. 29, no. 2, pp. 110-121.

Georgia Langer, 'Textuality, Sexuality, and the Nuances of Sex Work'

Chateauvert, M. 2014, Sex workers unite : A history of the movement from Stonewall to Slutwalk, Boston: Beacon Press.

Crabapple, M. 2019, 'It's not about sex', The New York Review of Books, vol. 66, no. 9, p. 10.

Cummins, C. personal communication, March 27, 2020

Dam, A. 2018, 'Analysis | Less than $1 \%$ of rapes lead to felony convictions. At least $89 \%$ of victims face emotional and physical consequences', viewed 10 May 2020, <https://www.washingtonpost.com/business/2018/10/06/less-than-percent-rapes-lead-felonyconvictions-least-percent-victims-face-emotional-physical-consequences/>.

Human Rights Campaign, 'Sexual assault and the LGBTQ community', viewed 5 May 2020, <https://www.hrc.org/resources/sexual-assault-and-the-lgbt-community>.

Intimate partner violence in LGBTQlLives, edited by Janice L. Ristock, viewed 5 May 2020, $<$ http://ebookcentral.proquest.com/lib/lewisclark/detail.action?docID=801882 .

MacKinnon, C. 1989, Toward a feminist theory of the state, Cambridge, Mass.: Harvard University Press.

McLeod, S. A. 2014, 'Techniques of compliance', Simply Psychology, viewed 5 May 2020, $<$ https://www.simplypsychology.org/compliance.html>.

Miller, L. E. 2019, A very offensive rom-com [podcast series episode], In Invisibilia, National Public Radio.

O'Connor, M. 2019, The sex economy (Gendered economy [Newcastle upon Tyne, England]). Newcastle upon Tyne: Agenda Publishing.

Penzer, N. 2016, Poison damsels: thieves, sacred prostitution and the romance of betel chewing (Kegan Paul library of arcana), London, [England]; New York: Routledge.

Prostitution in the United States. n.d. viewed 5 May 2020, <https://www.hg.org/legalarticles/prostitution-in-the-united-states-30997>.

Query, J., Montoya, John, Funari, Vicky, Query productions, \& First Run/Icarus Films, 2001, Live Nude Girls Unite! Brooklyn, NY: First Run/Icarus Films.

Quintana, G. R., Desbiens, S., Marceau, S., Kalantari, N., Bowden, J., \& Pfaus, J. G. 2019, 
'Conditioned partner preference in male and female rats for a somatosensory cue', Behavioral Neuroscience, vol. 133, no. 2, pp. 188-197.

Schulte, B. 2019, 'Revolting prostitutes: your socialism depends on it', Monthly Review, vol. 70, no. 11 , pp. 54-62.

Shepp, V., O'callaghan, E., Kirkner, A., Lorenz, K., \& Ullman, S. 2020, 'Sexual assault survivors who exchange sex: identity, stigma, and informal responses from support providers', Affilia, vol. 35, no. 1, pp. 105-128.

Smith, M., \& Mac, Juno. 2018, Revolting prostitutes: the fight for sex workers' rights, London ; Brooklyn, NY.

Tanenbaum, L. 1996, 'The sex police', Nation, vol. 263, no. 11, pp. 31-33.

Tarrant, S. 2016, The pornography industry: what everyone needs to know, New York, NY: Oxford University Press.

Williams, R., Elliott, I., \& Beech, A. 2013, 'Identifying sexual grooming themes used by internet sex offenders', Deviant Behavior, vol. 34, no. 2, pp. 135-152.

Josie Graydon, 'Public Transportation: A Vehicle for the Reduction of Social Inequalities'

Bamberg, S., Hunecke, M., \& Blöbaum, A. 2007, 'Social context, personal norms and the use of public transportation: Two field studies', Journal of Environmental Psychology, vol. 27, no. 3, pp. 190-203.

Boterman, W.R. \& Musterd, S. 2016, 'Cocooning urban life: Exposure to diversity in neighbourhoods, workplaces and transport', Cities, vol. 59, pp. 139-147.

Bullard, R.D. \& Johnson, G.S. 1997, Just transportation: dismantling race and class barriers to mobility, New Society Publishers, Gabriola Island, BC ; Stony Creek, CT.

Camagni, R., Gibelli, M.C., \& Rigamonti, P. 2002, 'Urban mobility and urban form: the social and environmental costs of different patterns of urban expansion', Ecological Economics, vol. 40, no. 2, pp. 199-216.

Elkin, L. 2015, 'Anyone over the age of thirty catching a bus can consider himself a failure': Class Mobility and Public Transport in Zadie Smith's NW', Études Britanniques Contemporaines, no. 49, viewed 24 February 2020, <http://journals.openedition.org/ebc/2679>.

Fleetwood, N. 2004, 'Busing It' in the City - Black Youth, Performance, and Public Transit.' TDR: The Drama Review, vol. 48, no. 2, pp. 33-48.

Flórez, J. 2000, 'Attracting higher income class to public transport in socially clustered cities. The case of Caracas. / Atracción del mayor nivel de ingresos al transporte público en las ciudades socialmente segregadas. El caso de Caracas.' Revista de Urbanismo, vol. 2, no. 2, pp. 98-112.

Gatersleben, B. \& Uzzell, D. 2007, 'Affective appraisals of the daily commute: comparing perceptions of drivers, cyclists, walkers, and users of public transport', Environment and Behavior, vol. 39, no. 3, pp. 416-431.

Giuliano, G. 2005, 'Low income, public transit, and mobility', Transportation Research Record, p. 8.

Heath, Y. \& Gifford, R. 2002, 'Extending the theory of planned behavior: predicting the use of public transportation', Journal of Applied Social Psychology, vol. 32, no. 10, pp. 2154-2189.

Holmgren, J. 2013, 'An analysis of the determinants of local public transport demand focusing the effects of income changes', European Transport Research Review, vol. 5, no. 2, pp. 101-07.

Mann, E. 1997, 'Confronting transit racism in Los Angeles', in R.D. Bullard \& G.S. Johnson 
(eds), Just Transportation: dismantling race and class barriers to mobility, New Society Publishers, Gabriola Island, BC ; Stony Creek, CT, pp. 68-83.

Nordfjærn, T., Şimşekoğlu, Ö., \& Rundmo, T. 2014, 'The role of deliberate planning, car habit and resistance to change in public transportation mode use', Transportation Research Part $F$ : Traffic Psychology and Behaviour, vol. 27, pp. 90-98.

Steg, L. 2003, 'Can public transport compete with the private car?', IATSS Research, vol. 27, no. 2, pp. 27-35.

Wickham, J. \& Lohan, M. 1999, 'The transport rich and the transport poor: car dependency and social class in four European cities', Urbanism and Suburbanism at the End of the Century, Employment Research Centre Department of Sociology Trinity College Dublin, Dublin, Ireland, pp. 1-26.

Wright, C. \& Egan, J. 2000, 'De-marketing the car', Transport Policy, vol. 7, no. 4, pp. 287-94.

Yeganeh, A.J., Hall, R.P., Pearce, A.R., \& Hankey, S. 2018, 'A social equity analysis of the U.S. public transportation system based on job accessibility', Journal of Transport and Land Use, vol. 11, no. 1, pp. 1039-56. 